\title{
Connecting natural and cultural heritage practices. Is integration always a good idea?
}

\author{
Marjo J. Schlaman \\ University of Amsterdam, ACASA - Department of Archaeology, Amsterdam, the \\ Netherlands
}

\begin{abstract}
Integrated approaches in landscape management are often seen as the way forward to provide solutions for complex heritage problems that are related to policy, climate change, tourism, environmental planning and involving the public. This has led to a range of interdisciplinary and multidisciplinary projects aiming to add value to disciplinary approaches and gain new insights. Although interdisciplinarity is a promising research approach, there are many obstacles that may affect the quality of the project outcomes, slow down the overall organisation or create substantive errors. This raises therefore the question: is integration always a good idea?

In this paper, I will show the complexity of cultural-historical landscapes and examine interdisciplinary approaches for their value as framework for historical landscapes. The role of historical assessments methods in landscape design is discussed. Finally, the example of two historical gardens and the process of their restoration and conservation will demonstrate how interdisciplinary and disciplinary approaches are related to each other in the garden design process.
\end{abstract}

Keywords: Cultural Heritage, Landscape, Historical Garden, Research Disciplines

\section{Introduction}

Over the last decade, the awareness of the interconnection between natural and cultural heritage have led to the adoption of integrated landscape management approaches by professionals of both domains. An integrated approach can explore alternative strategies as landscape policies with a traditional environmental and/or ecological focus are limited; it can also identify barriers to problem solving and provide alternative solutions offering a better basis for decision-making. Above all, it offers new insights into complex problems (Tress et al. 2003: 190). Such new approaches can lead to more efficient planning strategies, entail a more effective use of available resources, and ensure the actual integration of landscape into regional and town planning as well as into cultural, environmental, agricultural, social and economic policies. Multidisciplinary teams play more often a crucial role in applying joint approaches to the conservation, protection and management of archaeological and natural heritage (Tress et al. 2004: 485; Ndubisi 2002: 588).

Nevertheless, integrated approaches are no solution to each and any problem in the field 
of landscape heritage management and many of them do not exceed straightforward collaboration. Different disciplinary approaches still can be suitable for specific spatial environmental issues (Tress et al. 2003: 190). Choosing the right approach depends on the problem's definition and the project's goal, the applicability of theoretical frameworks, methods and philosophies, and organisational aspects such as funding, team size and coordination.

In this paper, I will explore the different management approaches by illustrating the restoration projects of two Dutch historical gardens, which can be both considered as particular landscapes in their own right.

\section{The garden as cultural-historical landscape}

In order to understand a garden as a cultural landscape, it is necessary to be aware of the reasons why landscapes are considered cultural heritage. Across time, humans have shaped their environment in order to satisfy their needs, either physical, aesthetical or spiritual (European Environment Agency 2010: 3). This is why landscapes are part of our culture and identity. Cultural landscapes are not just valued for their functional use like arable land, more often they are appreciated for aesthetic and recreational reasons (European Environment Agency 2010: 3, 5). As landscapes show the interaction between man and nature over the centuries, history is an important aspect to consider in cultural landscape studies (Drury 2002: 12). In addition, cultural-historical landscapes face a specific problem - how to go about knowing archaeological landscapes, since they are covered, in order to manage them in a sustainable way. These hidden landscapes represent the majority of cultural landscapes. They are sources of knowledge about past developments, people, and environments, containing 'unknown' information (Bloemers et al. 2010: XI). This is certainly true for historical gardens.

Since the late 1990s, in both landscape studies and archaeology, the relationship between people and the natural environment has developed from approaches oriented on the past that emphasised protection, maintaining and conserving, towards the future by including economic, social or environmental necessity, monitoring and sustainable planning (Council of Europe 2000; Ahern 2006: 128). Traditional environmental or ecological perspectives shifted to notions of sustainability in landscape research, policy, and management. This process of change was triggered by increasing public engagement with environmental issues such as spatial planning, pollution, overpopulation, recreation and tourism, as well as their effects on landscape resources (Cost 2010: 7). Although the cultivated and polished outlook of a garden may seem not to suffer from large-scale natural and planning processes, it is however affected by environmental changes such as rising or falling of water tables, air pollution, increasing numbers of tourists and expanding spatial planning processes. Managing these aspects requires awareness of the peculiarities of the cultural landscape including how people can be connected to the governance of them.

Already from the 1970s and 80s onwards, both in the research field of ecology and archaeology much attention has been given to human-nature relations (Bell 2004: 512). In a way, the acknowledgment of human-nature relations led to the integration of separate disciplines. In archaeology, this process often focused on landscape reconstruction over longer periods and food related subjects such as agricultural economy in the past (Bell, 2004: 513; Van der Valk 2010: 28). Although more recently research has emphasised the understanding of the archaeological-historical landscape with the purpose of integrating connected values such 
as landscape perception and societal needs within planning (Bloemers 2010: 4-6), the focus was mainly on integration of archaeology with disciplines belonging to the cultural heritage domain: historical geography and architectural history (Van der Valk 2010: 32). Nowadays, in both archaeology and historical ecology, the basic concept for a balanced future is the human-nature relationship that is found in sustainable development for future landscapes.

The human-nature relationship was acknowledged by the Council of Europe when interpreting the concept of 'landscape' as being the key element of individual and social well-being. Therefore, the protection, management and planning of landscapes entails rights and responsibilities for everyone (Council of Europe 2000: 2006). In this regard, the public should have the right to co-create their landscapes via planning and management. This recognition can be further developed by combining articulations of existing environmental and cultural rights that adds new features to be considered, such as the right of active public involvement in decisions that impact landscapes (Egoz et al. 2011: 7). The idea of the public having decisional rights on landscapes touches upon the intangible values landscapes have within ongoing natural and cultural changes. This should allow for more public engagement in policies governing landscapes.

As a consequence of the characteristics of cultural landscapes, future-oriented approaches such as adapted planning that includes accepting uncertainty and risk, and new scientific attitudes in the public discourse, multidisciplinary, transdisciplinary and integrated approaches are strived after within the research fields of landscape studies and archaeology (Ahern 2006: 126-127, 129). Academic disciplines and subdisciplines within the field of humanities, sciences and social sciences nowadays often look for cooperative ways to engage each other and stakeholders in landscape development (Tress et al. 2004: 483). However, landscape values and perception focus on understanding preferences, values, meanings, and experiences of people in interaction with the landscape that requires a far more complex approach than collaborative engagement. Ndubisi (2002: 408) for example, distinguishes three major starting points. Professionality, which is based on arts, design, and ecology, focusing primarily on visual experiences; behaviour, based on social and behavioural sciences, especially psychology, emphasizing visual and affective responses; humanistic, rooted in human geography, cultural anthropology, and phenomenological studies, stressing how relations between humans and landscapes are experienced. This relationship is often focal to archaeological landscape studies and was already examined by Christopher Tilley (1994). The question being, do we always need such a complex line of approach when it comes to cultural landscape management?

\section{Multidisciplinary and interdisciplinary approaches or is it disciplinary after all}

In search for integrated landscape management approaches, experts seek out new ways for collaboration and focus on methodological interdisciplinarity. One of the outcomes of the ANHER research project (Archaeological and Natural Heritage Management 2017) ${ }^{1}$ was that professionals of both the cultural and natural domain expected to apply interdisciplinary approaches by occasionally consulting experts such as environmental specialists, ecologists, construction engineers or soil experts. By doing so, they confirm their own role as specialists in cultural landscape projects and strengthened a disciplinary approach in the management of cultural landscapes, whether from a natural or cultural (archaeological) point of view

${ }^{1}$ The outcomes of the project ANHER were presented at the EAA 2017 meeting in Maastricht, the Netherlands. 
(Van Londen et al. 2015: 24-25). So, even within a shared work setting and despite crossing boundaries, disciplinary approaches do not necessarily change or lead to collaboration. Interdisciplinarity is therefore not a synonym for collaboration. Although the interest in teamwork to solve complex problems may lead to more interaction between different disciplines, collaboration does not always occur while a cooperative teamwork needs the collaboration of specialists (Klein 2017: 25). On the other hand, in practice, research disciplines are not islands drifting apart. All research fields blend and borrow ideas, metaphors and methods from other domains. Disciplines are not static, they do change and exchange. Especially disciplines in natural sciences, social sciences, and humanities are often grounded in methodological interdisciplinarity (Jacobs 2017: 37; Tress et al. 2003: 185).

\section{On terms and definitions}

As can be seen from the previous section, many concepts are unclear when it comes to new approaches in landscape management. What we exactly mean with the terms multidisciplinarity and interdisciplinarity, differ for each project description, research application or scientific tradition. Definitions of the main concepts used in the discussion on interdisciplinary and transdisciplinary studies are numerous and may often be confusing. Tress et al. (2003: 183) for example, suggest the following six definitions:

- "Disciplinarity: Projects that take place within the boundaries of currently recognized academic and/or professional disciplines, although these boundaries are dynamic.

- Multidisciplinarity: Projects that make a research effort of different academic disciplines and/or professional disciplines, related to one subject, but with multiple disciplinary goals. Participants exchange knowledge, but have not the aim to create new knowledge and theory. The project process disciplinary efforts without integration.

- Participatory projects: Professionals and non-professional participants are involved to solve a problem. Participants exchange knowledge, but the focus is not on the integration of the different knowledge cultures to create new knowledge. It can be a disciplinary or multidisciplinary project that includes non-professional participants.

- Interdisciplinarity: Projects that involve several unrelated academic disciplines, professions or specialisms in a way that forces them to cross subject boundaries to create new knowledge and theory and realize a common research goal.

- Transdisciplinarity: Projects that both integrate professionals from different unrelated disciplines and non-professional participants, such as land managers and the public, to research and/or realize a common goal and create new knowledge. These projects combine interdisciplinarity with a participatory approach.

- Integrated projects: These work either interdisciplinary or transdisciplinary, in that new knowledge and theory emerges from the integration of disciplinary knowledge."

An extra dimension on interdisciplinarity is offered by Klein (2017). She distinguishes methodological versus theoretical interdisciplinarity. Methodological interdisciplinarity 
aims to improve the quality of results by borrowing a method, for example surveying or sampling, or a concept such as 'exchange', from another discipline. As these practices do not lead to change in disciplinary relationships, disciplines are at most supplementary to each other. Methodological interdisciplinarity contributes to the needs of a specific domain or specialism, but grounds in disciplines (Klein 2017: 26). In theoretical interdisciplinarity a conceptual framework is created in order to analyse particular problems and provide a synthesis. This may be a single theoretical perspective that is applied to all disciplines. It may also be that problems lack any disciplinary basis. As a result of the interdisciplinary process methods can be modified and collaboration may lead to new methods and concepts (Klein 2017: 27). The last often used term is transdisciplinarity. This research is transgressive, as it creates new methodical and theoretical frameworks aiming for systematic integration of knowledge, reorganising knowledge by encompassing parts of several disciplinary fields, and prioritising problem solving. The basis is the problem itself, not the discipline. That is why mutual learning and evolvement of all stakeholders is key in transdisciplinarity (Klein 2017: 31).

\section{Is there a need for interdisciplinarity?}

It is commonly assumed that landscape research benefits from engaging with different planning and designing disciplines, along with exchanging knowledge amongst professionals, policy makers, practitioners and the wider public. During this process, specialist knowledge can be united with the expertise of policy makers and the understanding and aspirations of the public. The idea is that ultimately, this will lead to the engagement of all stakeholders involved in the field of landscape management, spatial planning and heritage, including political, academic, educational, non-governmental and voluntary parties, as well as sectors such as creative arts, landscape design, industry, commerce, and business (COST/ESF 2010). All these motivations have led to widespread multidisciplinary or interdisciplinary heritage projects and there are high expectations of the results that these new approaches can achieve (Tress 2003: 18). Terms like interdisciplinarity are often mentioned and seemingly applied in 'holistic' approaches or as the best method in problem solving for heritage management. They are however subject of a heated debate about the collaboration between researchers and private enterprises, or the way knowledge is produced in cooperation by academic experts and society as part of democratisation processes (Klein 2017: 33). In the end, many interdisciplinary projects combine separate disciplinary approaches without proactively integrating them around a question or problem (Klein 2017: 24).

Interdisciplinarity encounters the relationship between knowledge about complex and singular cases with knowledge about generalized concepts and causalities (Krohn 2017: 41). When applying interdisciplinary research to environmental planning it seems possible to transfer knowledge gained in one case to similar cases. However, relying on similarities without respecting differences in each situation can be misleading; every case may differ and needs another approach (Krohn 2017: 42). There is no denial that complex problems need to be addressed by interdisciplinary teams and that solutions for these problems may require coordinated efforts. Nevertheless, it does not mean that integrated research teams are needed to provide the knowledge base on which management strategies are based (Jacobs 2017: 38). Integration of disciplines is difficult and may take much longer than a single project. Also, interdisciplinary studies are no substitute for disciplinary efforts. They all are useful for specific problems or research questions (Tress et al. 2003: 184-185). This is illustrated by the following examples on the restoration and conservation of historical gardens. 


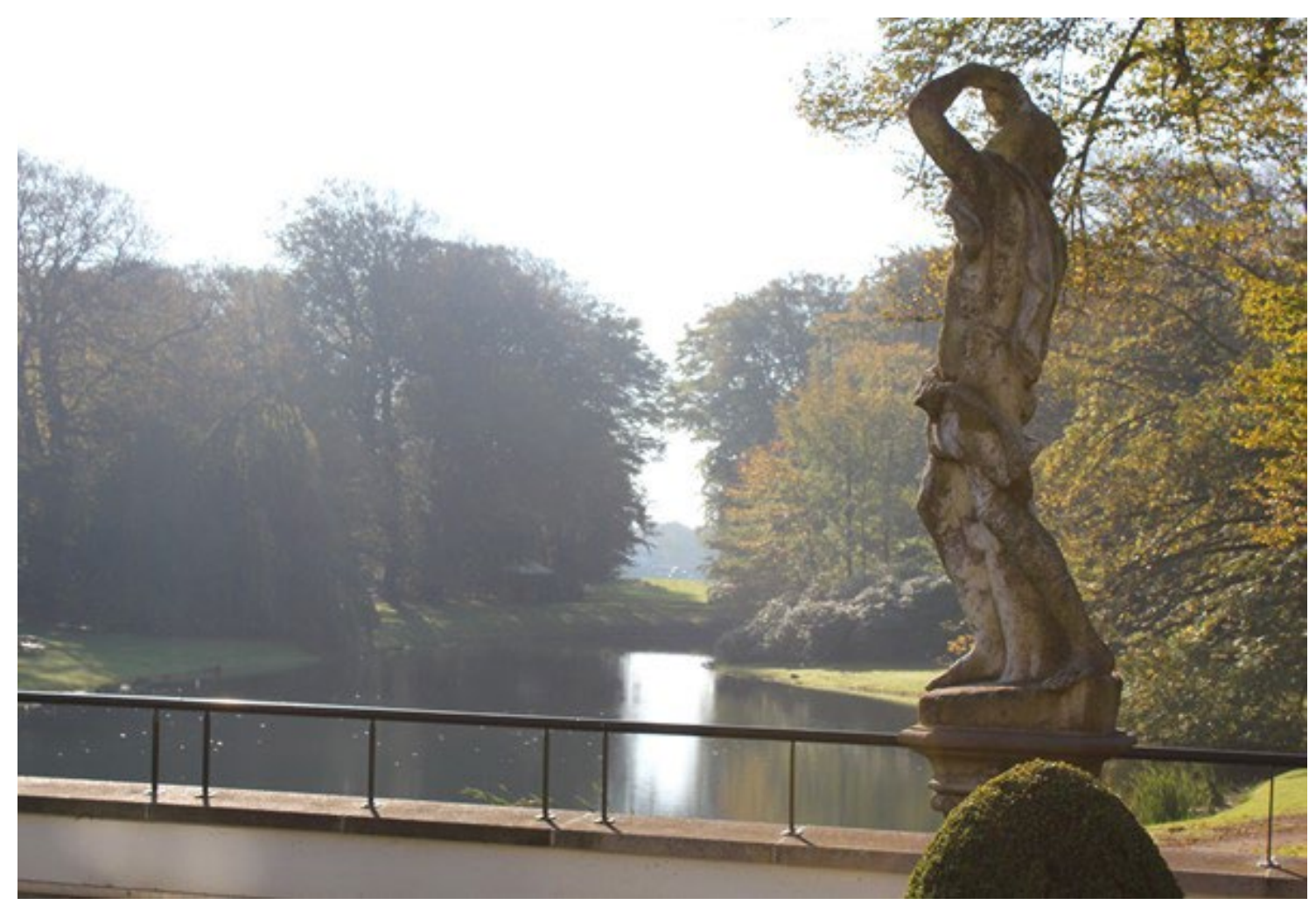

Figure 1. Viewing the surrounding landscape was an essential part of experiencing estates. Sightline at the back of the Manor House at Duin en Kruidberg in Santpoort-Noord (Photo G.A. Verschuure-Stuip, 2015).

\section{Country houses and estates}

Historical gardens at country houses and estates are eminently examples of places where cultural and natural values are intertwined. This follows from the idea that at these places, nature is submitted to design interests in relation to residencies. In garden design, the values of 'wild' nature are brought back into a controlled environment based on aesthetic qualities and with specific requirements for maintenance of the entire garden concerning both cultural and natural elements (Turner 2005: 29-30).

Nowadays, in north-western Europe, the management vision on the relationship between the environment and country houses or estates is characterized by the emphasis on design and protection. In the early $20^{\text {th }}$ century, the focus was on protecting parts of the estates, such as trees, tree stands, or house and other built objects. Later, attention was paid to the ensemble of house and garden. Since the 2000s, the focus is to include protection of the immediate and wider environment with specific emphasis on the scenic and situational aspects. Country houses and estates became themes in 'green' policy documents, regional and provincial structural visions (Verschuure-Stuip 2015: 18). In the Netherlands, some larger areas with several contiguous estates such as in the provinces of South-Holland and Utrecht, have been designated as protected monuments (Verschuure-Stuip 2015,18; Province South-Holland 2010: 18; Province Utrecht 2014: 9, 11). Currently, provincial policies aim for a comprehensive strategy to redefine conservation, development, and the finance of green heritage. This also includes citizens' and local residents' perception of and participation to green heritage. Country houses and estates are regarded as an important part of the inherent landscape characteristics and qualities (Verschuure-Stuip 2015: 18; Province Utrecht 2014: 7,9). 


\section{Recording historical values}

Provincial policies concerning the restoration and conservation of estates and country houses are put into practice through concepts such as the estate biotope. In this concept, spatial characteristic elements of a country house or estate are described and mapped (VerschuureStuip 2015: 19). The descriptions are primarily intended to make clear to developers and other stakeholders which elements in the environment of the estate's facilities are important. Therefore, they are recorded on a cultural-historical value map and become part of local spatial policy. A biotope has two aspects: the physical connection of the estate or country house to the environment (road, waterways) and the existing visual zones (from outside the estate overlooking the area), and what can be seen from the estates: the sightlines (Fig. 1) (Verschuure-Stuip 2015: 19).

Mapping the landscape biotope leads to an information database and can be used as inspiration for spatial planning. In the provinces of South-Holland and Utrecht, mapping is meant to be a resource for the various characteristics and spatial aspects of outdoor spaces. Mapping consists of a list of spatial and visual elements such as avenues, water, viewpoints, sightlines, buildings, gardens, park, and access structure, all emphasizing the coherence of the environment. On the maps, detailed elements are drawn (Fig. 2). All indicated elements on the map are precisely registered in a Geo Information System and can easily be combined with other (open) data, so to have a dynamic database (Verschuure-Stuip 2015: 20).

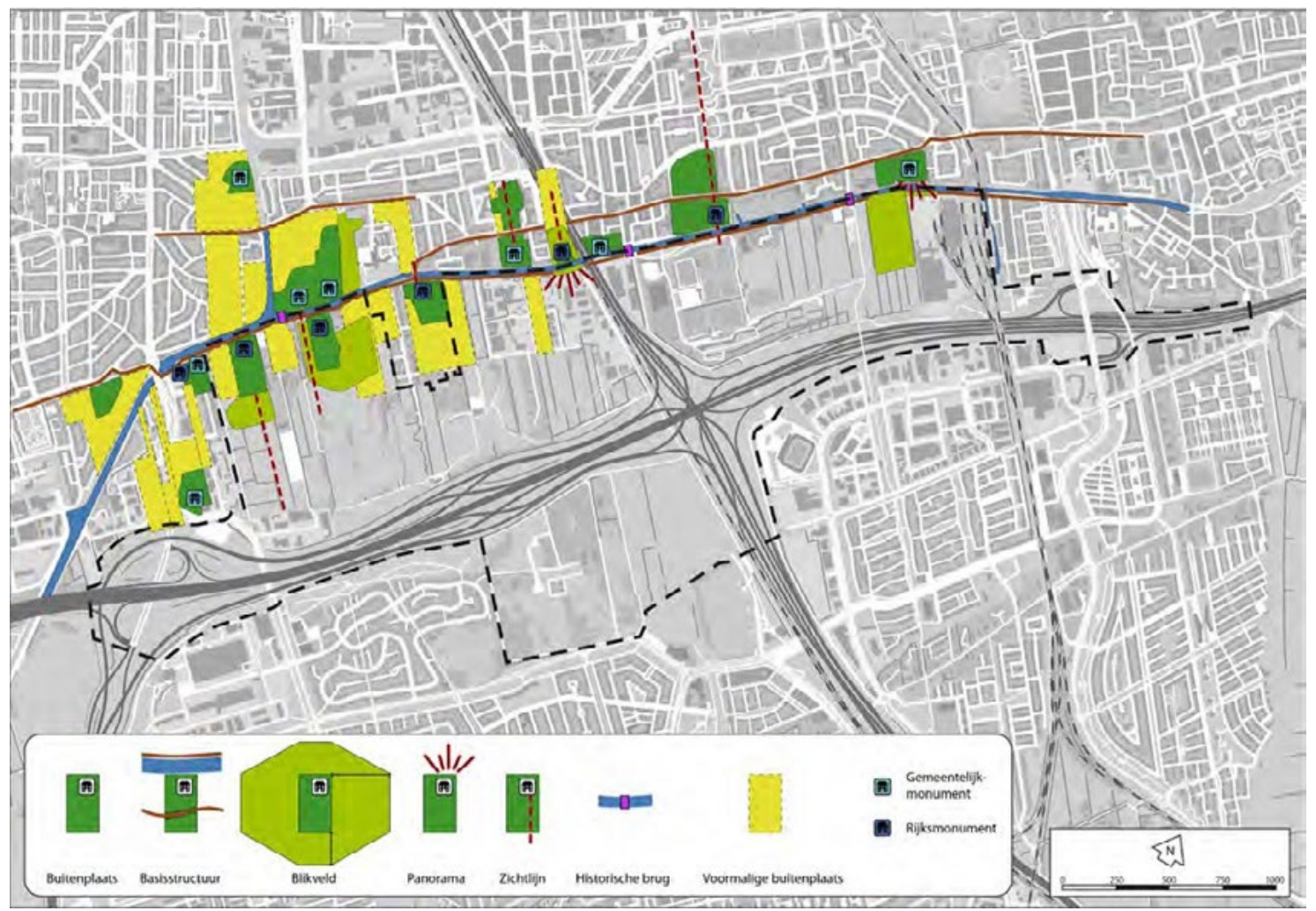

Figure 2. Landscape biotope Vlietzone Province South-Holland (The Hague, the Netherlands). 


\section{Conflicts in historical garden design, restoration and conservation}

The quality of restoration and conservation of historical gardens depends on the relationship between the architecture historian and the designer (mostly a landscape architect). The historian makes a mandatory value assessment of a historical green object. However, this historical value proposition, which focuses on user's value, only describes what is still present on the terrain. For example, a vanished seventeenth century lane structure is not part of the value proposition, while another structure that was added during the 1950s, is included. The method ignores changes through time and the overall structure and composition of the garden. A landscape architect then has to deal with historical values, guidelines for use, and governmental policy and legislation. Sometimes new features need to be incorporated in a historical object to comply with new regulations or future requirements (De Wit et al. 2011:37).

The practice of carrying out an historical value assessment that leads to subsequent protection clashes with the aim to increase the green object's value (Luiten 2006). The assessment method is based on buildings, and therefore centred on the static vision that something from the past can be restored or recreated. However, a garden or park is essentially different because of the variability and decline of the living material (De Wit et al. 2011: 38). Another problem that often occurs is that an historical green assessment only consists of an analysis of documents and an inventory of the garden itself. Foundations, plant holes and old paths, though, may lie beneath the surface. During a restoration, essential remaining information is often hidden or damaged (Doesburg et al. 2015: 4).

The often pragmatic use of historical sources in the design process asks for improvement on the actual handling of the historical characteristics of green heritage. Instead of only picking up the interesting historical elements, a designer could aim for convergence in landscape design (Luiten 2006). The design plan then, should provide information on the assessed values of the area by combining notions of past and future. Redesigning landscapes, including historic sites and associated valued resources, is a complex design brief for landscape architects. A dialogue between historians and archaeologists on one side, and designers and planners on the other side can avoid cultural heritage being an attractive animator for civic participation for spatial planning and decision making alone, instead of being a design goal. Key concepts for a fruitful design process are 'future historical value' and 'heritage development' (Luiten 2006).

\section{Restoration and conservation as part of the design process: Palace Het Loo}

Palace Het Loo was built as a hunting lodge in the 1680s and extended soon after Prince William III acquired the crown of England. A formal French Baroque garden was laid out at the palace with straight lanes and trimmed hedges similar to that of Versailles. Twelve years after construction the garden fell into a state of decay after the death of the King. In the $18^{\text {th }}$ century, the palace and the park were left largely unaltered (Ronnes 2015: 205). Louis Napoleon Bonaparte extensively renovated the palatial setting (area) in the $19^{\text {th }}$ century when an English landscape style garden was laid out, which changed the scenery into a more 'natural' environment in the tradition of landscape paintings. In the $20^{\text {th }}$ century, Queen Wilhelmina made further alterations. After her death in 1962, the restoration of both the palace and garden in the 1970s and 1980s regained a late $17^{\text {th }}$ century appearance (Ronnes 2015: 207).

The regeneration of the garden was highly debated -and still is- by scholars because by ignoring the changes made in the $18^{\text {th }}, 19^{\text {th }}$ and $20^{\text {th }}$ centuries, the actual history of the garden is neglected and offered to selective historical awareness (Von der Dunk 2006: 117; Ronnes 


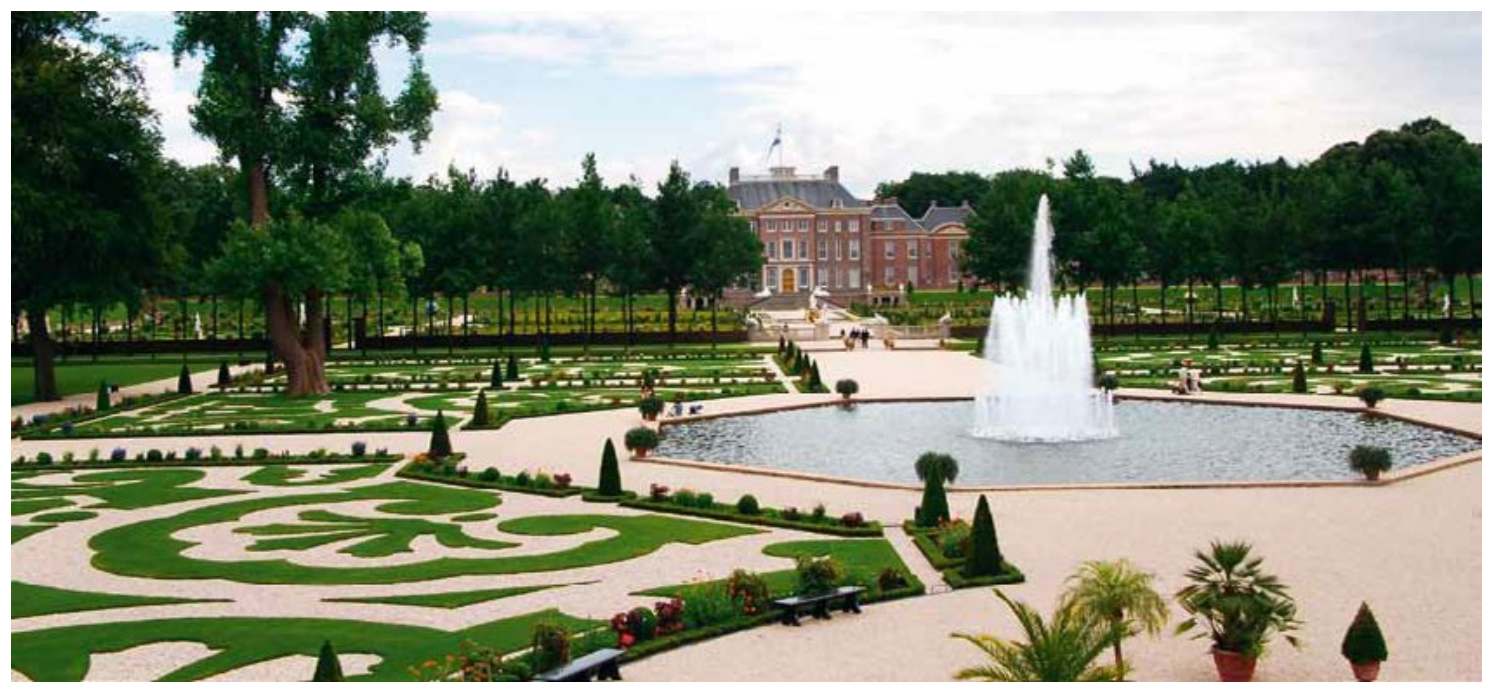

Figure 3. Restored $17^{\text {th }}$ century garden of Palace Het Loo, Apeldoorn (De Wit et al. 2011).

2015: 230). Criticism regarding the reconstruction plans for the gardens of Het Loo concerned in particular the dismantling of the publicly valued landscape garden, which represented almost two centuries of history, and the reconstruction of the formal garden, whereby the original design aimed at the unification of palace and garden would be lost (Fig. 3) (Ronnes 2010: 193).

At the palace gardens, gradually all the evidence of later periods have been removed to show the classical garden as it was for only twelve years in the $17^{\text {th }}$ century. The reconstruction was meant to be an "almost literal" copy of the original garden. Unearthed fragments of the basins and separation walls, historical documentation and prints were used as a guide to reconstruct the $17^{\text {th }}$ century situation, leading to a classical style garden within a extensive landscape which has remained largely intact. The scarcity of authentic parts in the garden explains the importance that is attached to trees as real relics. Some trees belonging to the former landscape garden of Het Loo were spared in the restoration as a compromise with the opponents of the reconstruction. These trees remained standing as scenic additions (Von der Dunk 2006: 117; Ronnes 2010: 193).

As for many multidisciplinary approaches in heritage management, the nature often is the stronger party, possessing more resources, stronger political influence, and more know-how on how to state interests and to achieve goals (Skoglund \& Svensson 2010: 370). During the restoration process of the garden, the natural elements were considered more important than the actual cultural history of the garden. Cultural heritage is only the stronger party on the aspect that it is less disputed by people than nature (Skoglund \& Svensson 2010: 380). The archaeological remains in the garden were covered after excavation, thus limiting the historical information available to the designers. For example, in 2003 archaeologists detected the remains of a sloping basin in the upper garden which included two canopies (resting places), a fountain, a cascade, volutes, pipes, and mosaics. After the excavation, it was decided to bring back the place to its 'original' state by reconstructing a new ensemble and covering up the archaeological remains (Ronnes 2010: 194). Nature conservation organizations made in this case use of the cultural heritage agenda for communicating nature conservation concerns. As a result, the restored garden exists twice as long as the original one designed in the $17^{\text {th }}$ century (Fig. 4). 


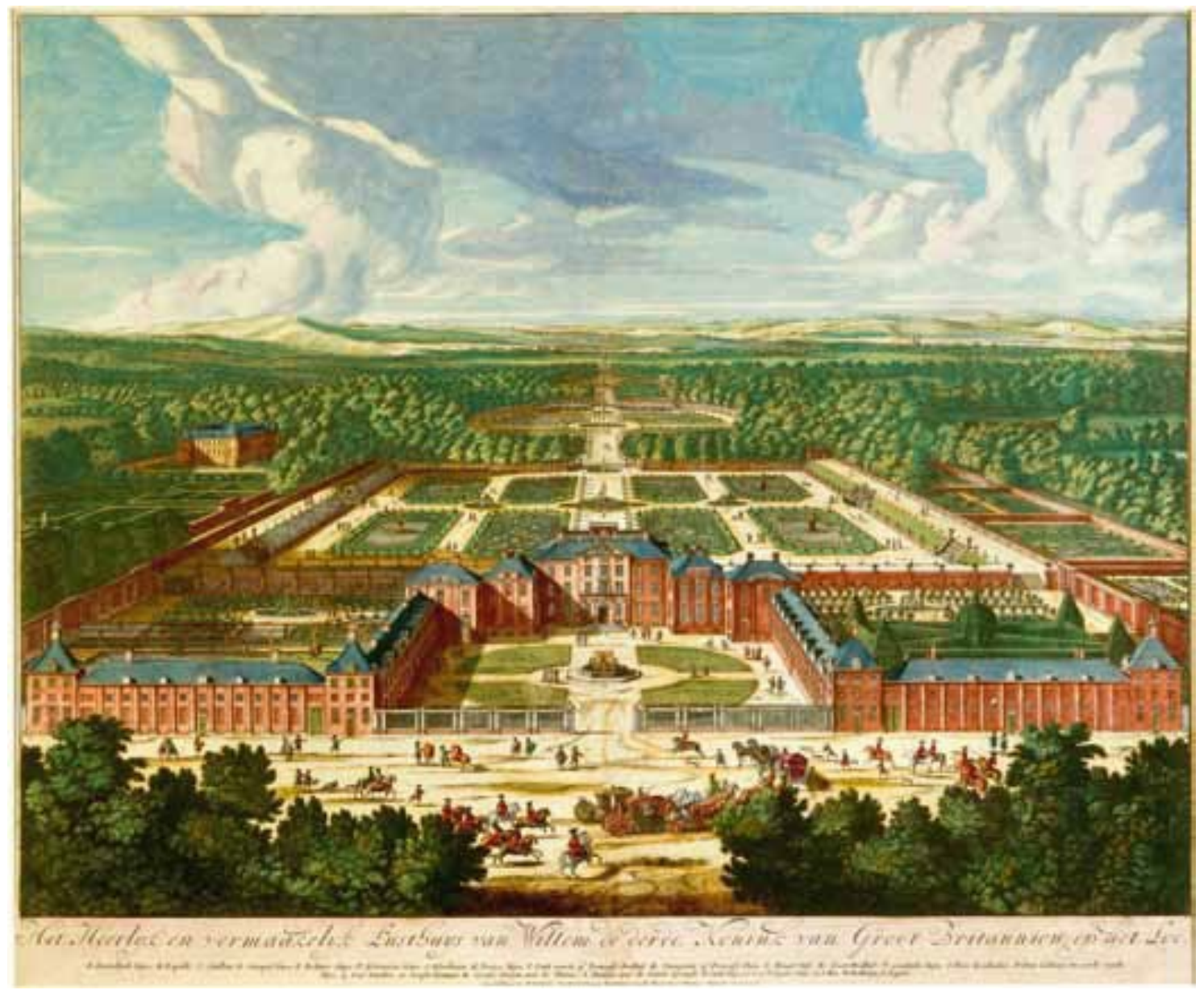

Figure 4. Birdseye view of Palace Het Loo by P. Schenck (Palace Het Loo National Museum Apeldoorn).

\section{Archaeology as part of the design process: Castle Duivenvoorde}

According to the archival and iconographic sources, the garden around Duivenvoorde is at least four hundred years old. It developed over different periods, from 'sleek' to 'romantic' to 'natural' (figure 5). The castle was built in the $13^{\text {th }}$ century in a marshy area behind the dunes on a rectangular island surrounded by a moat. A map from 1615 shows an impressive geometric park around the castle: a rectangular construction of waterways and canals, with a vegetable garden and an orchard. The terrain also includes pigeon houses, tenant houses, and a farm with stables. A major renovation in 1631 transformed the medieval castle into a comfortable country house. At the same time avenues, boulevards and graceful parterres were added to the garden (Van Doesburg et al. 2015).

In former studies, archaeologists traced remnants of the old garden at Duivenvoorde and labelled them as 'historical distortion' (Van Doesburg et al. 2015: 6). An innovative, comprehensive approach and new research was made possible by restoration activities carried out to open the gardens to the public. This approach led to more specific archaeological questions such as of whether what appears on the historical maps corresponds to what might be found underground; the materials and methods used three hundred years ago for the construction of paths, ponds and sheet piles; and knowledge of the past vegetation through botanical research (Van Doesburg et al. 2015: 6). 


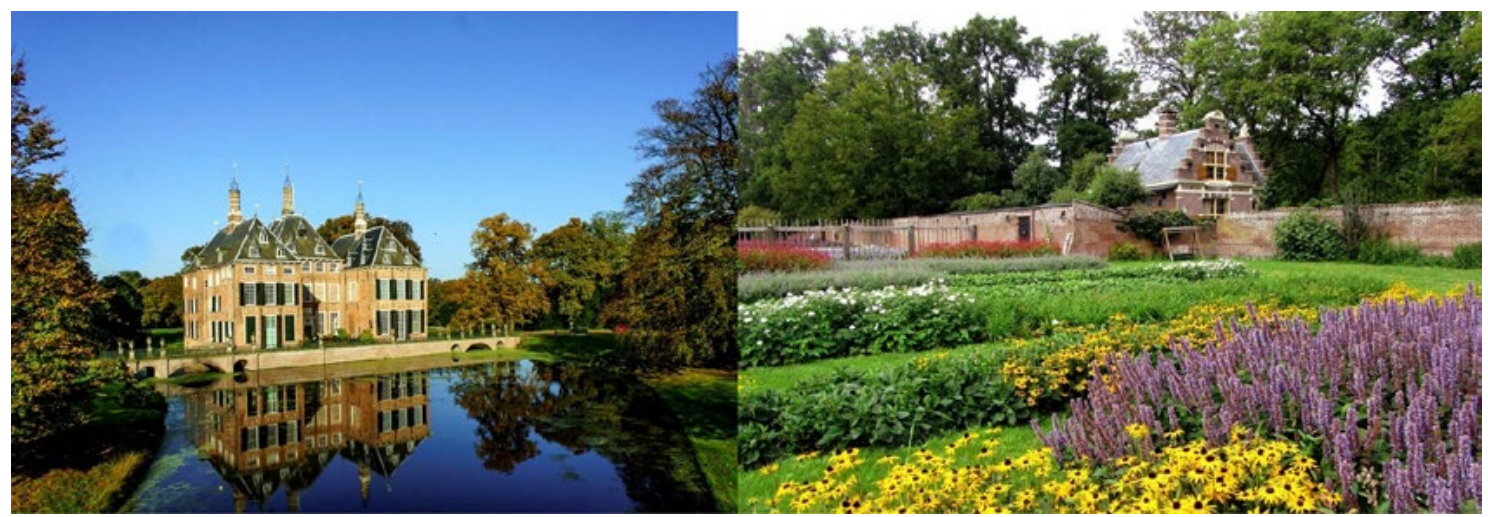

Figure 5. Manor house and gardens of estate Duivenvoorde (www.kasteelduivenvoorde.nl).

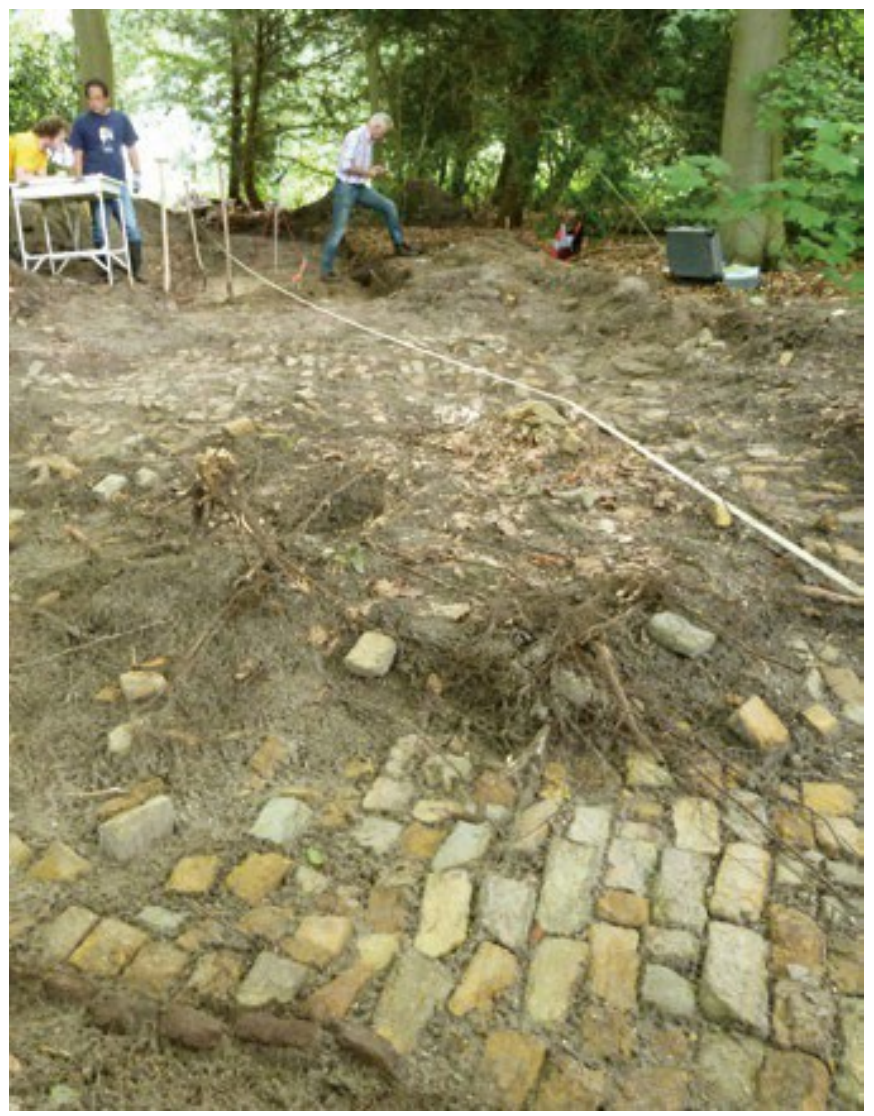

Figure 6. Archaeological research unearthed directly underneath the $20^{\text {th }}$ century grass sods and paths from the $19^{\text {th }}$ century (Tijdschrift van de Rijksdienst voor het Cultureel Erfgoed, RCE, Amersfoort, the Netherlands)
To determine the most promising research locations, archaeologists used a historical map of 1717 , then those areas have been investigated through digging, coring and mechanical drilling.

It turned out that during the development of the landscape garden much soil was replaced and, in some places more than a meter deep. This meant that all older tracks were erased. By using a metal detector, archaeologists could map the nineteenth-century path structure (figure 6). Additionally, trenches with the remains of two ponds were suitable for botanical research as these preserved organic residues such as twigs, seeds and pollen (Van Doesburg et al. 2015: 7).

\section{Conclusion}

Both studies on historical gardens show the context in which an integrated strategy can be developed and applied over time. Cultural history, archaeology and nature preservation were explored in the context of research projects that span from disciplinary approaches to collaborative attempts for integration. They demonstrate how much complex interdisciplinarity may be and how often it is mistaken for being a better practice as opposed to disciplinary strategies. On the contrary, adopting an interdisciplinary perspective is not always the way to add value to the outcome of projects. A practical approach based on a common research goal and a research/project management 
strategy that involves critical awareness of methods and theory of other disciplines seem to be a necessity. For an integrated approach, the phase of defining the commongoal should take sufficient time to all participants.

In order to achieve a better work process in the management of historical gardens and their restoration or renovation, it is important to look at the methods and techniques that are currently available. As mentioned above, the historical value assessment is based on historical architecture. To avoid such an approach, the historical value proposition should be part of a multidisciplinary value proposition. This proposition combines historical value, environmental value, spatial value, and use value as comparable and independent variables, including management and exploitation. Ecological value propositions may be available, but are mostly limited to measuring flora and fauna on a larger scale than the historical value proposition, which makes them incomparable (De Wit et al. 2011: 40). By appointing heritage management as starting point for the (re)design of a garden, growth and decay (the history of nature) can be visualised as a characteristic feature of the garden (De Wit et al. 2011: 40). In addition, knowledge of the remains underground provides better preservation. When authentic material can be stored, such as the paving of the paths, the quality of the restoration will increase. In return, it will raise the quality of future research, because the material is preserved as a source of information. Garden archaeology is a relatively new development and this specific archaeological research needs research questions, methods and techniques that are tailored to every specific situation (Van Doesburg et al. 2015: 7).

As integrated approaches are currently pushed and driven forward by funding agencies and research policy, the investment in integrated problem solutions may fail when expectations are high. The restoration and conservation of the garden of palace Het Loo faced the problem of an integrated approach that led to criticism and a public debate on the value of cultural history and authenticity versus ecological lobby and a wide range of opinions. The outcome of the debate hardly served the project's goal. At Castle Duivenvoorde, the choice of a parallel disciplinary approach did add value to the garden restoration and is therefore a successful step towards interdisciplinarity. Due to a renovation or restauration, architectural historians and archaeologists had to work together to gain insight into each other's work and vision. Cooperation with local historians, residents and managers also increases mutual knowledge. Garden archaeology then brings together disciplines and expertise, and broadens the view on the interaction between people and gardens (Van Doesburg et al. 2015: 7). Although the project's processes had a different course, the outcomes have led to attractive touristic features that are acknowledged as green monuments. Disciplinarity is after all a strong base for outreach towards another specialism, domain or field of knowledge.

\section{References}

Ahern, J., 2006. Theories, methods and strategies for sustainable landscape planning. From landscape research to landscape planning. Aspects of integration, education and application, Dordrecht, Springer, 119-131.

Bell, M., 2004. Archaeology and Green Issues, in: J. Bintliff (ed.) A Companion to Archaeology, Malden (MA), Oxford (UK), Victoria (AU): Blackwell Publishing, 509-531.

Bloemers, T., 2010. Introduction, in: T. Bloemers, H. Kars, A. Van der Valk, M. Wijnen (eds), The Cultural Landscape \& Heritage Paradox. Protection and Development of the Dutch Archaeological-Historical Landscape and its European Dimension. Amsterdam: Amsterdam 
University Press, 3-16.

Bloemers T., Kars, H., Van der Valk, A. \& Wijnen, M., (eds), 2010. Preface, in: T. Bloemers, H. Kars, A. Van der Valk, M. Wijnen (eds), The Cultural Landscape \& Heritage Paradox. Protection and Development of the Dutch Archaeological-Historical Landscape and its European Dimension. Amsterdam: Amsterdam University Press, XI-XII.

COST 2010. Landscape in a Changing World. Bridging divides, integrating disciplines, serving society. Science policy briefing (41). Brussels: European Science Foundation.

Council of Europe 2000. European Landscape Convention. Florence, Italy.

Council of Europe 2006. Landscape and sustainable development: challenges of the European Landscape Convention.

De Wit, S., Huls, M., Van der Meulen, B., 2011. Gestapelde tijd. Historische tuinen als eigentijdse ontwerpopgave. Blaune Kamer 5, 36-41. Drury P., 2002. The historic and cultural dimensions of landscape. Naturopa 98, 12-13.

European Environment Agency 2010. 10 messages for 2010. Cultural landscapes and biodiversity heritage. Copenhagen: European Environment Agency.

Egoz, S., Makhzoumi, J., Pungetti, G., (eds) 2011. The right to landscape: contesting landscape and buman rights. London: Ashgate.

JacoBs, J.A., 2017. The Need for Disciplines in the Modern Research University, in: Frodeman, R. (ed.), The Oxford Handbook of Interdisciplinarity (2nd ed.). Accessed January 2018. Online Publication Date: March 2017. Oxford: Oxford University Press, 36-40.

KLEIN, J.T., 2017. Typologies of Interdisciplinarity: The Boundary Work of Definition, in: Frodeman, R. (ed.), The Oxford Handbook of Interdisciplinarity (2nd ed.). Accessed January 2018. Online Publication Date: March 2017. Oxford: Oxford University Press, 21-35.

KroHn, W., 2017. Interdisciplinary Cases and Disciplinary Knowledge: Epistemic Challenges of Interdisciplinary Research, Frodeman, R. (ed.), The Oxford Handbook of Interdisciplinarity (2nd ed.). Accessed January 2018. Online Publication Date: March 2017. Oxford: Oxford University Press, 41-53.

Londen, H. van, Schlaman, M. J., Travaglia, A., 2015. Survey of good Vocational Education \& Training practices and learning needs in the Dutch cultural and green heritage sectors ANHER Project_ O1-A3 Dutch National Report Output 1. Amsterdam: University of Amsterdam.

Luiten, E., 2006. Tot hier... en nu verder: ruimtelijk ontwerp en historisch besef. Oration held in acceptance of the chair of Cultural History and Design at the Faculty of Architecture at Delft University of Technology, Delft.

Ndubisi, F., 2014. A synthesis of approaches to Ecological Planning, in NdubisI, F. (ed.), The ecological design and planning reader. Washington DC: Island Press, 404-426.

Province South-Holland, 2010. Tussen 'Rusten Vreugd' en 'In de Werelt is veel Gevaar', Actualisatie buitenplaatsen CHS; de buitenplaatsbiotoop in Zuid-Holland. The Hague: Province South-Holland. Province Utrecht, 2014. De Utrechtse Buitenplaatsbiotoop, Kenmerken en Ambities. Utrecht: Province Utrecht.

Ronnes, H., 2010. Authenticiteit en authenticiteitsbeleving: de presentatie en receptieve van museum Paleis Het Loo. Bulletin KNOB 109 (5), 190-199. RonNes, H., 2015. The quiet authors of an early modern palatial landscape: Transformation without reconstruction at King William's Het Loo, in: J. Kolen, H.Renes \& R. Hermans (eds), Landscape Biographies. Geographical, Historical and Archaeological Perspectives on the Production and Transmission of Landscapes. Amsterdam: Amsterdam University Press, 205-233. Skoglund, P. \& Svensson, P., 2010. Discourses of nature conservation and heritage management in the past, present and future: Discussing heritage and sustainable development 
from Swedish experiences. EJA 13 (3), 368-385.

Tilley, C.,1994. A phenomenology of Landscape. Oxford (UK), Providence (USA): Berg Publishers.

Tress, G., 2003. On policy expectations, in: B. Tress, G.Tress, A. Van der Valk \& G. Fry (eds), Interdisciplinary and Transdisciplinary Landscape Studies: Potential and Limitations. Accessed January 2016. Wageningen: Delta Series 2, 18. http://www.tress.cc/delta/series2.html Tress, B., Tress, G., \& Fry, G., (eds) 2003. Potential and limitations of interdisciplinary and transdisciplinary landscape studies, in: B. Tress, G. Tress, A. Van der Valk \& G. Fry (eds), Interdisciplinary and Transdisciplinary Landscape Studies: Potential and Limitations. Accessed January 2016. Wageningen: Delta Series 2, 18. http://www.tress.cc/delta/series2.html 182-192.

Tress, B., Tress, G. \& Fry, G., 2004. Clarifying integrative research concepts in landscape ecology. Landscape Ecology 20, 479-493.

Turner, T., 2005, Design philosophy 2000 BC-2000 AD, in: Garden History Philosophy and Design 2000 BC-2000 AD. London, New York: Spon Press, 1-33.

Van der Valk, A., 2010. Planning the past. Lessons to be learned from 'Protecting and Developing the Dutch Archaeological-Historical Landscape' (PDL/BBO), in: T. Bloemers, Kars, H., Van der Valk, A. \& Wijnen, M., (eds), The Cultural Landscape \& Heritage Paradox. Protection and Development of the Dutch Archaeological-Historical Landscape and its European Dimension. Amsterdam: Amsterdam, University Press, 21-51.

Van Doesburg, J., Lensvelt, N., Van der Heiden, M., 2015. Het park van Kasteel Duivenvoorde, Tuingeschiedenis gaat ondergronds in Tuinarcheologie. Tijdscbrift van de Rijksdienst voor het Cultureel Erfgoed 7(3). Amersfoort: RCE, 4-7.

VON DER Dunk, T., 2006. De moeizame vormgeving van ons verleden. Bulletin KNOB 105 (4), 108-122.

Verschunre-Stuip, G.A., 2015. De Buitenplaatsbiotoop of landgoedbiotoop. Nieuwe allianties in de bescherming van buitenplaatsen en landgoederen (Zuid-Holland en Utrecht). Vitruvius 9 (33). Rotterdam: Educom, 14-19. 